\title{
Cellular Transplantation for Liver Diseases
}

\author{
Elizabeth Jameson
}

\begin{abstract}
Presently, the orthotropic liver transplantation (OLT) is still the most effective therapeutic for patients with acute or chronic hepatic failure. However, due to the shortage of donor livers, the number of patients benefited from this approach is limited. Therefore, some alternative modalities have been paid attention for restoring the liver function. The cell transplantation is one of the promising modalities to realize this purpose. The types of cells used in the cell transplantation include syngeneic hepatocytes, allogeneic hepatocytes, immortalized hepatocytes, and stem cells derived heptocytes. The stem cells, especially the adult stem cells from bone marrow, are shown as a promising cell source for liver repopulation. The mesenchymal bone marrow stem cells and embryonic stem cells can be induced to differentiate into the hepatic lineage and might be used in the cell transplantation for liver diseases. Compared to OLT, the advantages of cell-based therapy for liver disease are, but not limited to, less invasive, less expensive, easy manipulated, easy expansion of cells in vitro. Cells can be stored in a cell bank for future use. Though most of the current studies are experimental and animal based, the cellular therapy for liver disease is expected to be an effective alternative in clinical settings in near future.
\end{abstract}

Key words: cell transplantation, liver failure, stem cells, orthotropic liver transplantation

Manuscript received October 16, 2008; accepted November 5, 2008

The authors declare no conflict of interest.

Department of Medicine, McGill University, 3655 Promenade Sir William Osler, Montreal, Quebec, Canada, H3G 1Y6

Email: elizabeth.jameson@elf.mcgill.ca

doi:10.4021/gr2008.11.1243

\section{Introduction}

Up to now, orthotropic liver transplantation (OLT) is still the most effective treatment of a variety of life-threatening liver diseases, however, due to the shortage of donors, the number of patients who can benefit from this modality is very limited(1,2). In recent years, cell based therapies have been investigated as alternatives to whole liver transplantation. There are some advantages of cellular transplantation over whole liver transplant. A single donor liver could be shared by multiple patients; it is less invasive, procedures are safer and easier to manage, multiple treatments can be carried out on a single patient(3); only 1-5 percent of the total hepatocytes mass transplantation could correct a variety of metabolic disorders(1); the hepatocytes can be manipulated in vitro easily, such as genetic manipulation $(3,4)$. This brief review summarizes some highlights in the cellular transplantation in the treatment of liver diseases, such as the source of cells, routes of transplantation, and indications of transplantation.

\section{Potential clinical applications of cellular transplantation for liver diseases}

\section{Bridging patients with liver failure to whole liver transplan-} tation

This is to improve the patient's condition and extend short-term survival until a donor liver becomes available or until the patient's own liver recovers $(3,5,6)$. Previous clinical observations using liver cell transplantation for the hepatic failure showed that the patients' condition was transiently improved and thus successfully bridged to $\operatorname{OLT}(5,7)$.

\section{Correction of inborn errors of metabolism}

The studies of cellular transplantations for inborn errors of metabolism have been conducted both in animal models(8-14) and in humans(15-18). These animal models with genetic liver defects include Gunn rat, which lacks hepatic bilirubin UDP-glucuronosyl transferase actificty (UGT1A1), and the Nagase analbuminemic rat model(19, 20). Allogeneic hepatocytes transplantation 
was used as a treatment for inherited glycogen storage type $1 \mathrm{a}(21)$ and the crigler-Najjar syndrome type $\mathrm{I}(16)$.

\section{Liver failure and cirrhosis}

When patients with acute liver failure were transplanted allogeneic hepatocytes, clinical improvement was observed though the donor hepatocytes constitute approximately $1 \%$ to $10 \%$ of the liver mass. However, there was no survival improvement in the extremely sick patients(6).

The causes of liver disease often involve exposure to extrinsic agents, especially drugs or environmental toxins, which induce acute to subacute hepatocellular disease(3). The thearapeutic significance of hepatocytes transplantation is likely to be disease context-dependent. In the Dgalactosamine model, there was increased survival after transplantation of hepatocytes subcellular fractions, culture supernatants or even bone marrow cells, these results indicate that the early therapeutic effect requires only cell-derived factors(22-24) for the first 3-5 days after induction of acute liver failure. After this period, the transplanted hepatocytes will repopulate and proliferate with reorganization to restore liver function, and reproduce fully normal hepatic tissue, this process needs several weeks or months(3), thus, it is of significance for the treatment of chronic liver disease, such as liver cirrhosis(25).

\section{Types of cells for transplantation in liver diseases}

\section{Primary hepatocytes}

The adult primary hepatocytes were used commonly in experimental and pre-clinical studies(26). These cells include allogeneic, xenogeneic or autologus primary isolated hepatocytes. Primary xenogenic hepatocytes seems to be an unlimited source of hepatocytes and can solve the human donor shortage(27-30). When the porcine hepatocytes transplantated into a rat cirrhotic model, it can correct liver function(29). However, using xenogenic hepatocytes transplantation may incur some concerns, such as xenozoonoses, xenoantifenicity(31), and immunorejection, host versus graft reaction(32).

\section{Immortalized cell lines}

The immortalized heaptocytes are derived from gene transfer(32-48) in vitro. The conditionally immortalized rat hepatocytes by transduction using the simian virus 40 $\mathrm{T}$ antigen(SV40 Tag) can lower the risk of transplanted hepatocyte malignant transformation(49), because after excision of the SV40Tag, these immortalized hepatocytes can stop growing and the differentiated characteristics are enhanced(50). These conditionally immortalized cell lines transplantation in rats with end-stage liver failure can provide life-supporting liver-specific metabolic function(49). When immortalized heaptocytes isolated from P19ARF null mice were intrasplenically transplanted into Fasinjured liver of SCID mice (severe combined immuno- deficiency), the cells participated the liver repopulating and regenerating process, and were capable of generating hepatic progenitor cells during liver restoration(51).

Hepatocyte-like cells derived from adult bone marrow stem cells

Previous studies showed that bone marrow cells contains a subpopulation of hepatocytes-orientated stem cells expressing a-AFP, c-met, CD34 and c-kit(31, 52, 53). These cells in vitro and in vivo can differentiated into hepatocytes(5456) with the capacity of reversing liver failure(56), and synthesizing albumin in the lethally irradiated mice(57).

\section{Hepatocyte-like cells derived from embryonic stem cells}

The embryonic stem cells can differentiate into hepatocytes in vitro(58-60) and in vivo(61, 62). The embryonic stem cells could differentiate into hepatocytes under specific culture conditions. Mouse embryonic stem cells were able to grow and showed morphology consistent with typical mature hepatocytes and expressed hepatocytes specific genes, when these cells transplanted into the carbon tetrachloride-injured mouse liver, they were able to incorporated into liver tissue and rescued mice from hepatic injury(63). The embryonic stem cells derived hepatocytes have been found to be effective in a liver failure mouse model induced by diphtheria toxin(64).

\section{Routes of cell transplantation}

\section{Intraperitoneal injection}

The peritoneal cavity is a commonly used site for cell implantation(65). The peritoneal cavity has a large space into which a remarkable number of cells can be transplanted.

\section{Intrahepatic transplantion}

The intrahepatic transplantation of normal hepatocytes can prevent Wilson's disease in these LEC rats(66). In another study, the intrahepatic transplantation of human hepatocytes in immunodeficient, fumarylacetoacetate hydrolase-deficient (fah(-/-) mice, three months after transplantation, about $20 \%$ of the mouse liver was observed repopulated by human hepatocytes, and sustained expression of lentiviral vector transduced gene(67).

\section{Portal veinous infusion}

Hepatocytes can be seeded into the liver by portal vein infusion and the transplanted hepatocytes can integrate into the liver cords, leaving the hepatic architecture intact(68). Hepatocytes engrafted in the liver have the benefits of exposure to the portal nutrients, contacting with other hepatocytes and nonparenchymal cells, thus have the ability to secrete bile into the indigenous biliary system (33).

\section{Intrasplenic infusion}

doi:10.4021/gr2008.11.1243 
Intrasplenic transplantation is another route of cell delivery for the liver diseases. Previous studies showed that intrasplenic transplantation of hepatocytes increased survival of the totally hepatectomized rats(69). The intrasplenic transplantation of human fetal immortal hepatocytes could prolong survival of $90 \%$ hepatectomized rats(70). After massive hepatectomy, such as in $90 \% \mathrm{PH}$, or under the situation that the diseased liver is not a suitable site for cell transplantation, the intrasplenic cell transplantation may become an ideal alternative. Hepatocytes can be injected into the splenic pulp from which most cells translocate to the liver through the splenic vein, a small fraction of the cells engraft within the spleen and can develop into bile cannuliculae, sinusoidal structures, and endothelial cells, producing a similar structure to the liver( 71,72$)$.

\section{Storage and availability of cells}

Isolated hepatocytes can be stored in a cryopreserved hepatocytes bank. Since human liver cells are sensitive to damage due to the freezing-thawing procedure, reliable procedures for long-term cryopreservation of human hepatocytes need to be investigated(1). The major concern of using heaptocytes is the lack of donor availability, in addition, the cryopreserved liver cells have not yet been shown to engraft as well as fresh hepatocytes(73).

\section{Immunorejection}

To solve the shortage of donor livers, researchers turn to the cells from animal sources, the animal source seems to be an unlimited supply. However, the xeno-transplantation can cause host immunorejection and the immunosuppressive agents must be used $(10,74)$

\section{Considerations for future studies}

Though some positive results obtained in the cell based therapy for liver disease either in animal or clinical studies, there are, however, still some important theoretical and practical issues that need to be addressed. Firstly, whatever transplantation route employed, the cells engraftment and cell efficacy are crucial points(75), the functions of transplanted cells are closely related to the engraftment rate. The use of better quality cells and regeneration stimulus can improve the engraftment $(76,77)$. Secondly, if stem cell derived hepatocytes are used, these cells may have potential of malignant transformation. Thirdly, except the autologus or syngeneous cell sources, the allogeneic or xenogeneic cell transplantation needs co-administration of immunosuppressive agents which may aggravate or contraindicate the patients' illness.

\section{Conclusions}

Cellular therapy is a promising approach for the liver diseases, although there are a number of issues unsolved. With the cellular and molecular biology advancement, it is hopeful that cell transplantation will be developed into a standard therapy for liver failure or inborn metabolic diseases in the future.

\section{References}

1. Muraca M. Cell therapy as support or alternative to liver transplantation. Transplant Proc 2003;35:1047-1048.

2. Fiegel HC, Kaufmann PM, Bruns H, Kluth D, Horch RE, Vacanti JP, Kneser U. Hepatic tissue engineering: from transplantation to customized cell-based liver directed therapies from the laboratory. J Cell Mol Med 2008; 12:56-66.

3. Braun KM, Degen JL, Sandgren EP. Hepatocyte transplantation in a model of toxin-induced liver disease: variable therapeutic effect during replacement of damaged parenchyma by donor cells. Nat Med 2000;6:320326.

4. Nussler A, Konig S, Ott M, Sokal E, Christ B, Thasler $\mathrm{W}$, Brulport M, et al. Present status and perspectives of cell-based therapies for liver diseases. J Hepatol 2006;45:144-159.

5. Strom SC, Fisher RA, Thompson MT, Sanyal AJ, Cole PE, Ham JM, Posner MP. Hepatocyte transplantation as a bridge to orthotopic liver transplantation in terminal liver failure. Transplantation 1997;63:559-569.

6. Bilir BM, Guinette D, Karrer F, Kumpe DA, Krysl J, Stephens J, McGavran L, et al. Hepatocyte transplantation in acute liver failure. Liver Transpl 2000;6:32-40.

7. Strom SC, Chowdhury JR, Fox IJ. Hepatocyte transplantation for the treatment of human disease. Semin Liver Dis 1999;19:39-48.

8. Wilson JM, Chowdhury NR, Grossman M, Wajsman R, Epstein A, Mulligan RC, Chowdhury JR. Temporary amelioration of hyperlipidemia in low density lipoprotein receptor-deficient rabbits transplanted with genetically modified hepatocytes. Proc Natl Acad Sci U S A 1990;87:8437-8441.

9. Chowdhury JR, Grossman M, Gupta S, Chowdhury NR, Baker JR, Jr., Wilson JM. Long-term improvement of hypercholesterolemia after ex vivo gene therapy in LDLR-deficient rabbits. Science 1991;254:1802-1805.

10. Gunsalus JR, Brady DA, Coulter SM, Gray BM, Edge AS. Reduction of serum cholesterol in Watanabe rabbits by xenogeneic hepatocellular transplantation. Nat Med 1997;3:48-53.

11. Matas AJ, Sutherland DE, Steffes MW, Mauer SM, Sowe A, Simmons RL, Najarian JS. Hepatocellular transplantation for metabolic deficiencies: decrease of plasms bilirubin in Gunn rats. Science 1976;192:892-894. 
12. Moscioni AD, Rozga J, Chen S, Naim A, Scott HS, Demetriou AA. Long-term correction of albumin levels in the Nagase analbuminemic rat: repopulation of the liver by transplanted normal hepatocytes under a regeneration response. Cell Transplant 1996;5:499-503.

13. Oren R, Dabeva MD, Petkov PM, Hurston E, Laconi E, Shafritz DA. Restoration of serum albumin levels in nagase analbuminemic rats by hepatocyte transplantation. Hepatology 1999;29:75-81.

14. Nguyen TH, Birraux J, Wildhaber B, Myara A, Trivin F, Le Coultre C, Trono D, et al. Ex vivo lentivirus transduction and immediate transplantation of uncultured hepatocytes for treating hyperbilirubinemic Gunn rat. Transplantation 2006;82:794-803.

15. Grossman M, Raper SE, Kozarsky K, Stein EA, Engelhardt JF, Muller D, Lupien PJ, et al. Successful ex vivo gene therapy directed to liver in a patient with familial hypercholesterolaemia. Nat Genet 1994;6:335341.

16. Fox IJ, Chowdhury JR, Kaufman SS, Goertzen TC, Chowdhury NR, Warkentin PI, Dorko K, et al. Treatment of the Crigler-Najjar syndrome type I with hepatocyte transplantation. N Engl J Med 1998;338:1422-1426.

17. Lake JR. Hepatocyte transplantation. N Engl J Med 1998;338:1463-1465.

18. Chowdhury JR, Chowdhury NR, Strom SC, Kaufman SS, Horslen S, Fox IJ. Human hepatocyte transplantation: gene therapy and more? Pediatrics 1998;102:647648.

19. Rugstad HE, Robinson SH, Yannoni C, Tashjian AH, Jr. Transfer of bilirubin uridine diphosphate-glucuronyltransferase to enzyme-deficient rats. Science 1970;170:553-555.

20. Fabrega AJ, Bommineni VR, Blanchard J, Tetali S, Rivas PA, Pollak R, Sengupta K, et al. Amelioration of analbuminemia by transplantation of allogeneic hepatocytes in tolerized rats. Transplantation 1995;59:1362-1364.

21. Muraca M, Gerunda G, Neri D, Vilei MT, Granato A, Feltracco P, Meroni M, et al. Hepatocyte transplantation as a treatment for glycogen storage disease type 1a. Lancet 2002;359:317-318.

22. Wesolowska A, Olszewski WL, Durlik M. Transplantation of hepatocytes: elimination of recipient natural killer cells with irradiation and bone marrow reconstitution prevent early graft dysfunction. Transplant Proc 2003;35:2358-2360.

23. Kuai XL, Cong XQ, Li XL, Xiao SD. Generation of hepatocytes from cultured mouse embryonic stem cells. Liver Transpl 2003;9:1094-1099.

24. Theise ND. Liver stem cells: the fall and rise of tissue biology. Hepatology 2003;38:804-806.

25. Gagandeep S, Rajvanshi P, Sokhi RP, Slehria S, Palestro CJ, Bhargava KK, Gupta S. Transplanted hepatocytes engraft, survive, and proliferate in the liver of rats with carbon tetrachloride-induced cirrhosis. J Pathol 2000;191:78-85.

26. Machimoto T, Yasuchika K, Komori J, Ishii T, Kamo N, Shimoda M, Konishi S, et al. Improvement of the survival rate by fetal liver cell transplantation in a mice lethal liver failure model. Transplantation 2007;84:12331239.

27. Mai G, Huy NT, Morel P, Mei J, Bosco D, Berney T, Majno P, et al. Treatment of fulminant liver failure by transplantation of microencapsulated primary or immortalized xenogeneic hepatocytes. Transplant Proc 2005;37:527-529.

28. Nishitai R, Koch CA, Ogata K, Knudsen BE, Plummer TB, Butters KA, Platt JL. Toward the survival and function of xenogeneic hepatocyte grafts. Liver Transpl 2005;11:39-50.

29. Nagata H, Ito M, Cai J, Edge AS, Platt JL, Fox IJ. Treatment of cirrhosis and liver failure in rats by hepatocyte xenotransplantation. Gastroenterology 2003;124:422431.

30. Ishikawa F, Drake CJ, Yang S, Fleming P, Minamiguchi $\mathrm{H}$, Visconti RP, Crosby CV, et al. Transplanted human cord blood cells give rise to hepatocytes in engrafted mice. Ann N Y Acad Sci 2003;996:174-185.

31. Di Campli C, Gasbarrini G, Gasbarrini A. Review article: a medicine based on cell transplantation -- is there a future for treating liver diseases? Aliment Pharmacol Ther 2003;18:473-480.

32. Stockmann HB, JN IJ. Prospects for the temporary treatment of acute liver failure. Eur J Gastroenterol Hepatol 2002; 14:195-203.

33. Fox IJ, Chowdhury JR. Hepatocyte transplantation. Am J Transplant 2004;4 Suppl 6:7-13.

34. Delgado JP, Parouchev A, Allain JE, Pennarun G, Gauthier LR, Dutrillaux AM, Dutrillaux B, et al. Long-term controlled immortalization of a primate hepatic progenitor cell line after Simian virus 40 T-Antigen gene transfer. Oncogene 2005;24:541-551.

35. Kim BH, Han YS, Dong SH, Kim HJ, Chang YW, Lee JI, Chang R. Temporary amelioration of bilirubin conjugation defect in Gunn rats by transplanting conditionally immortalized hepatocytes. J Gastroenterol Hepatol 2002;17:690-696.

36. Kobayashi N, Westerman KA, Taguchi T, Sakaguchi M, Fujiwara T, Urata H, Kishimoto N, et al. Expansion of human hepatocyte populations by a retroviral gene transfer of simian virus 40 large $\mathrm{T}$ antigen. Asaio J 2001;47:481-485.

37. Kobayashi N, Miyazaki M, Westerman KA, Noguchi H, Sakaguchi M, Totsugawa T, Watanabe T, et al. Construction of a differentiated human hepatocyte cell line expressing the herpes simplex virus-thymidine kinase gene. Asaio J 2001;47:476-480.

38. Fukaya K, Asahi S, Nagamori S, Sakaguchi M, Gao 
C, Miyazaki M, Namba M. Establishment of a human hepatocyte line (OUMS-29) having CYP 1A1 and 1A2 activities from fetal liver tissue by transfection of SV40 LT. In Vitro Cell Dev Biol Anim 2001;37:266-269.

39. Kaulek V, Saas P, Alexandre E, Grant H, Richert L, Jaeck D, Tiberghien P, et al. Comparative phenotype and immunogenicity of freshly isolated and immortalized rat hepatocytes. Cell Transplant 2001;10:739-747.

40. Kobayashi N, Fujiwara T, Westerman KA, Inoue Y, Sakaguchi M, Noguchi H, Miyazaki M, et al. Prevention of acute liver failure in rats with reversibly immortalized human hepatocytes. Science 2000;287:1258-1262.

41. Kosuga M, Enosawa S, Li XK, Suzuki S, Matsuo N, Yamada M, Roy-Chowdhury J, et al. Strong, long-term transgene expression in rat liver using chicken betaactin promoter associated with cytomegalovirus immediate-early enhancer (CAG promoter). Cell Transplant 2000;9:675-680.

42. Allen KJ, Reyes R, Demmler K, Mercer JF, Williamson $\mathrm{R}$, Whitehead RH. Conditionally immortalized mouse hepatocytes for use in liver gene therapy. J Gastroenterol Hepatol 2000;15:1325-1332.

43. Liu J, Pan J, Naik S, Santangini H, Trenkler D, Thompson N, Rifai A, et al. Characterization and evaluation of detoxification functions of a nontumorigenic immortalized porcine hepatocyte cell line (HepLiu). Cell Transplant 1999;8:219-232.

44. Chamuleau RA. Bioartificial liver support anno 2001. Metab Brain Dis 2002; 17:485-491.

45. Kobayashi N, Westerman KA, Tanaka N, Fox IJ, Leboulch $\mathrm{P}$. A reversibly immortalized human hepatocyte cell line as a source of hepatocyte-based biological support. Addict Biol 2001;6:293-300.

46. Cascio SM. Novel strategies for immortalization of human hepatocytes. Artif Organs 2001;25:529-538.

47. Kobayashi N, Miyazaki M, Fukaya K, Inoue Y, Sakaguchi M, Uemura T, Noguchi H, et al. Transplantation of highly differentiated immortalized human hepatocytes to treat acute liver failure. Transplantation 2000;69:202207.

48. Kobayashi N, Miyazaki M, Fukaya K, Inoue Y, Sakaguchi M, Noguchi H, Matsumura T, et al. Treatment of surgically induced acute liver failure with transplantation of highly differentiated immortalized human hepatocytes. Cell Transplant 2000;9:733-735.

49. Cai J, Ito M, Nagata H, Westerman KA, Lafleur D, Chowdhury JR, Leboulch P, et al. Treatment of liver failure in rats with end-stage cirrhosis by transplantation of immortalized hepatocytes. Hepatology 2002;36:386394.

50. Cai J, Ito M, Westerman KA, Kobayashi N, Leboulch P, Fox IJ. Construction of a non-tumorigenic rat hepatocyte cell line for transplantation: reversal of hepatocyte immortalization by site-specific excision of the SV40 T antigen. J Hepatol 2000;33:701-708.

51. Mikula M, Fuchs E, Huber H, Beug H, Schulte-Hermann R, Mikulits W. Immortalized p19ARF null hepatocytes restore liver injury and generate hepatic progenitors after transplantation. Hepatology 2004;39:628-634.

52. Oh SH, Miyazaki M, Kouchi H, Inoue Y, Sakaguchi M, Tsuji T, Shima N, et al. Hepatocyte growth factor induces differentiation of adult rat bone marrow cells into a hepatocyte lineage in vitro. Biochem Biophys Res Commun 2000;279:500-504.

53. Miyazaki M, Akiyama I, Sakaguchi M, Nakashima E, Okada M, Kataoka K, Huh NH. Improved conditions to induce hepatocytes from rat bone marrow cells in culture. Biochem Biophys Res Commun 2002;298:24-30.

54. Fiegel HC, Lioznov MV, Cortes-Dericks L, Lange C, Kluth D, Fehse B, Zander AR. Liver-specific gene expression in cultured human hematopoietic stem cells. Stem Cells 2003;21:98-104.

55. Petersen BE, Bowen WC, Patrene KD, Mars WM, Sullivan AK, Murase N, Boggs SS, et al. Bone marrow as a potential source of hepatic oval cells. Science 1999;284:1168-1170.

56. Lagasse E, Connors H, Al-Dhalimy M, Reitsma M, Dohse M, Osborne L, Wang X, et al. Purified hematopoietic stem cells can differentiate into hepatocytes in vivo. Nat Med 2000;6:1229-1234.

57. Wang X, Ge S, McNamara G, Hao QL, Crooks GM, Nolta JA. Albumin-expressing hepatocyte-like cells develop in the livers of immune-deficient mice that received transplants of highly purified human hematopoietic stem cells. Blood 2003;101:4201-4208.

58. Hamazaki T, Iiboshi Y, Oka M, Papst PJ, Meacham AM, Zon LI, Terada N. Hepatic maturation in differentiating embryonic stem cells in vitro. FEBS Lett 2001;497:1519.

59. Jones EA, Tosh D, Wilson DI, Lindsay S, Forrester LM. Hepatic differentiation of murine embryonic stem cells. Exp Cell Res 2002;272:15-22.

60. Yamada T, Yoshikawa M, Kanda S, Kato Y, Nakajima $\mathrm{Y}$, Ishizaka S, Tsunoda Y. In vitro differentiation of embryonic stem cells into hepatocyte-like cells identified by cellular uptake of indocyanine green. Stem Cells 2002;20:146-154.

61. Chinzei R, Tanaka Y, Shimizu-Saito K, Hara Y, Kakinuma S, Watanabe M, Teramoto K, et al. Embryoid-body cells derived from a mouse embryonic stem cell line show differentiation into functional hepatocytes. Hepatology 2002;36:22-29.

62. Choi D, Oh HJ, Chang UJ, Koo SK, Jiang JX, Hwang $\mathrm{SY}$, Lee JD, et al. In vivo differentiation of mouse embryonic stem cells into hepatocytes. Cell Transplant 2002;11:359-368.

63. Yamamoto H, Quinn G, Asari A, Yamanokuchi H, Teratani T, Terada M, Ochiya T. Differentiation of embryon- 
ic stem cells into hepatocytes: biological functions and therapeutic application. Hepatology 2003;37:983-993.

64. Ishii T, Yasuchika K, Machimoto T, Kamo N, Komori J, Konishi S, Suemori H, et al. Transplantation of embryonic stem cell-derived endodermal cells into mice with induced lethal liver damage. Stem Cells 2007;25:32523260 .

65. Demetriou AA, Levenson SM, Novikoff PM, Novikoff AB, Chowdhury NR, Whiting J, Reisner A, et al. Survival, organization, and function of microcarrier-attached hepatocytes transplanted in rats. Proc Natl Acad Sci U S A 1986;83:7475-7479.

66. Yoshida Y, Tokusashi Y, Lee GH, Ogawa K. Intrahepatic transplantation of normal hepatocytes prevents Wilson's disease in Long-Evans cinnamon rats. Gastroenterology 1996;111:1654-1660.

67. Bissig KD, Le TT, Woods NB, Verma IM. Repopulation of adult and neonatal mice with human hepatocytes: a chimeric animal model. Proc Natl Acad Sci U S A 2007;104:20507-20511.

68. Ponder KP, Gupta S, Leland F, Darlington G, Finegold M, DeMayo J, Ledley FD, et al. Mouse hepatocytes migrate to liver parenchyma and function indefinitely after intrasplenic transplantation. Proc Natl Acad Sci U S A 1991;88:1217-1221.

69. Vogels BA, Maas MA, Bosma A, Chamuleau RA. Significant improvement of survival by intrasplenic hepatocyte transplantation in totally hepatectomized rats. Cell Transplant 1996;5:369-378.

70. Kobayashi N, Miyazaki M, Fukaya K, Noguchi H,
Tanaka N, Namba M. Intrasplenic transplantation of immortalized human fetal hepatocytes prolongs the survival of $90 \%$ hepatectomized rats. Transplant Proc 2000;32:2365-2367.

71. Kusano M, Mito M. Observations on the fine structure of long-survived isolated hepatocytes inoculated into rat spleen. Gastroenterology 1982;82:616-628.

72. Mito M, Kusano M, Onishi T, Saito T, Ebata H. Hepatocellular transplantation --morphological study on hepatocytes transplanted into rat spleen. Gastroenterol Jpn 1978;13:480-490.

73. David P, Alexandre E, Audet M, Chenard-Neu MP, Wolf P, Jaeck D, Azimzadeh A, et al. Engraftment and albumin production of intrasplenically transplanted rat hepatocytes (Sprague-Dawley), freshly isolated versus cryopreserved, into Nagase analbuminemic rats (NAR). Cell Transplant 2001;10:67-80.

74. Ito Y, Chang TM. In vitro study of multicellular hepatocyte spheroids formed in microcapsules. Artif Organs 1992;16:422-427.

75. Smets F, Najimi M, Sokal EM. Cell transplantation in the treatment of liver diseases. Pediatr Transplant 2008;12:6-13.

76. Gupta S, Gorla GR, Irani AN. Hepatocyte transplantation: emerging insights into mechanisms of liver repopulation and their relevance to potential therapies. J Hepatol 1999;30:162-170.

77. Grompe M, Laconi E, Shafritz DA. Principles of therapeutic liver repopulation. Semin Liver Dis 1999;19:714. 